\title{
EDELLISEN KYLMÄN SODAN LOPPU
}

\section{Ulf Sundqvist}

VTM, Helsinki
Maailma elää tällä hetkellä kriittistä aikaa. On alkanut kuulua puhetta uuden kylmän sodan uhkasta.

Viime vuosikymmeninä maailmassa on koettu jännitystä milloin mistäkin syystä. Kansainvälinen terrorismi, alueelliset sotatoimet, pakolaisongelmat ja kyberhyökkäykset ovat olleet arkipäivää. Yhä kasvavat ympäristöongelmat ja vahvistunut tietoisuus meneillään olevasta ilmastomuutoksesta ovat antaneet leimansa kuluvan vuosituhannen alkuvuosille.

Maailmanpolitiikassa on nyt meneillään muutos, joka saattaa olla odottamattoman syvä. Suurvaltasuhteissa on tapahtumassa uusjako. Yhdysvaltain ja Kiinan väliset suhteet ovat kiristymässä, minkä seurauksena on syntymässä uusia konstellaatioita. Idän ja lännen välinen ristiriita on saamassa uutta sisältöä.

Poliittisen ja sotilaallisen jännityksen ohella taustalla vaikuttaa kasvavassa määrin teknologiakilpailu siihen liittyvine "kybersodan" ilmiöineen.

Edellisen kylmän sodan elementit ovat luonnollisesti vielä olemassa ydinasearsenaalien ja jättimäisen konventionaalisen asekapasiteetin myötä. Globaalitasolla roolijako on muuttunut. Venäjä on edelleen sotilaallinen suurvalta, mutta talouden ja teknologian osalta maan suurvalta-asema on kovasti rapistunut.

Euroopan poliittinen tulevaisuus on sisäisesti vasta muotoutumassa, ja ulkoisesti Eurooppa on edelleen hakemassa asemaansa globaalilla näyttämöllä. Tämä hakuprosessi on nyt ollut käynnissä yli 30 vuotta, edellisen kylmän sodan loppuvaiheesta saakka, mikä vain osoittaa, että poliittiset muutosprosessit vievät aina aikaansa - etenkin demokraattisten muutosten osalta.

Vuonna 1991 tapahtui äkillinen muutos, jota laajasti on luonnehdittu "kylmän sodan lopuksi". Muutoksen aiheutti Neuvostoliiton poliittinen kriisi, joka tosin oli alkanut vuosikausia aikaisemmin huipentuen lopulta elokuun 1991 epäonnistuneeseen vallankaappausyritykseen ja koko Neuvostoliiton hajoamiseen vuoden lopulla. Merkittävä seuraus tästä oli kansainvälisen kommunismin luhistuminen. Vain Kiina ja muutama muu maa tunnustaa edelleen kommunismin väriä.

Neuvostoliiton kaatumisen syitä on vuosien varrella analysoitu perusteellisesti. Suurvallan keskitetty, kommunistiseen puoluevaltaan perustunut järjestelmä oli tullut tiensä päähän. Uudistumiskyky oli kadonnut, maa oli joutunut sosiaaliseen ja moraaliseen kriisiin. Talous oli taantunut, ja investoinnit pysähtyneet, samoin teknologinen kehitys. Tämä johti tappioon myös asevarustelukilpailussa. Maa oli joutunut umpikujaan.

Kun Mihail Gorbatšov nousi NKP:n johtoon ja sen jälkeen maan presidentiksi, hän käynnisti kunnianhimoisen uudistusohjelman, perestroikan, jonka tavoitteena oli talouden perinpohjainen uudistaminen. Hanke kuitenkin epäonnistui sen vuoksi, ettei ollut edellytyksiä eikä aikeitakaan uudistaa poliittista päätöksentekojärjestelmää. Gorbatšov uskoi voivansa uudistaa yhteiskunnan ja talousjärjestelmän keskusjohtoisen kommunismin puitteissa. Se osoittautui mahdottomaksi.

Gorbatšovin toinen uudistusohjelma, glasnost, tähtäsi yhteiskunnan avaamiseen, sanan- 
vapauden laajentamiseen ja kriittisen keskustelun sallimiseen. Se oli tervetullut muutos, mutta nosti vastareaktioita konservatiivien ja valtakoneiston piirissä. Gorbatšovin avaukset länteen ja hänen aktiivinen liennytyspyrkimyksensä aiheuttivat nekin vastarintaa.

Kahdeksankymmenluvun loppupuolella Itä-Euroopassa alkoi esiintyä yhä laajempaa liikehdintää. Järjestelmäkritiikki yltyi Puolassa, Unkarissa, Tšekkoslovakiassa, Romaniassa ja Itä-Saksassa. Myös Neuvostoliitto sai kokea tämän kansallisen heräämisen omalla alueellaan. Baltian maiden itsenäistymispyrkimykset vahvistuivat, ja Venäjä alkoi esiintyä omissa nimissään - Ukraina ja eteläiset osatasavallat niin ikään. Koko itäblokki oli vapisemassa.

Lopputuloksen tiedämme. Unkari avasi rajansa itäsaksalaisille, Berliinin muuri kaadettiin, ja Saksat päätettiin yhdistää. Kaikissa Itä-Euroopan maissa vahvistuivat muutosprosessit. Tämä kaikki tapahtui Gorbatšovin johtaman Neuvostoliiton tieten ja nähden.

Elokuun 19. päivänä 1991 panssarivaunut valtasivat Moskovan keskustan kadut. NKP:n ja voimakoneiston konservatiiviset voimat olivat päättäneet iskeä. Vallankaappaus oli päätetty toteuttaa presidentti Gorbatšovin ollessa lomalla Krimillä. Varapresidentti Gennadi Janajevin johdolla kaappausta johtanut komitea julisti maahan poikkeustilan ja ilmoitti presidentin olevan terveydellisistä syistä estynyt johtamaan maata. Tosiasiassa Gorbatšov vaimoineen oli siirretty kotiarestiin.

Vallankaappaus kesti kolme päivää, kunnes ilmeni, että koko operaatio oli huonosti suunniteltu ja surkeasti toteutettu. Pian kävi selväksi, etteivät kaduille komennetut sotilaat olleet valmiit käyttämään aseita protestoivia kansalaisia vastaan. Venäjän presidentti Boris Jeltsin nousi parlamentin edessä panssarivaunun päälle ja julisti vallankaappauksen mitättömäksi. Kaappaajat antautuivat, ja heidät pidätettiin. Kaksi poikkeustilakomitean jäsentä teki itsemurhan, ja toiset tuomittiin aikanaan eripituisiin rangaistuksiin.
Syksyn 1991 aikana itäisen naapurimaamme kohtalo sinetöitiin - Neuvostoliitto hajosi. Maan kommunistinen puolue lakkautettiin, samoin Varsovan liitto. Mihail Gorbatšov erosi NL:n presidentin tehtävästä, ja Venäjän presidentti Boris Jeltsin ryhtyi hallitsemaan. Suurvalta oli supistunut Venäjän Federaatioksi. Kylmä sota oli sillä kertaa päättynyt, ja sen itäinen osapuoli oli muutosten kourissa.

Maailma muuttui. Eurooppa laajeni ja integraatio eteni. Baltian maat, Ukraina, ValkoVenäjä ja Neuvostoliiton eteläiset osatasavallat itsenäistyivät. Gorbatšovin aikaiset liennytystoimet ja varustelusupistukset pysyivät voimassa.

Neuvostoliiton hajoaminen ja Euroopan suuret muutokset muuttivat kertaheitolla Suomen sodanjälkeisen aseman. Saksan yhdistymisen seurauksena Suomi teki yksipuolisen päätöksen Pariisin rauhansopimuksen aserajoituspykälien irtisanomisesta. Neuvostoliitto ja Britannia hyväksyivät päätöksen Pariisin allekirjoittajavaltioiden puolesta

Neuvostoliiton kriisin edetessä Suomessa oli hyvissä ajoin alettu valmistautua YYA-sopimuksen irtisanomiseen ja uuden, Suomen ja Venäjän suhdetta säätelevän sopimuksen valmistamiseen. Sopimus solmittiin vuoden 1992 alussa. Presidentti Mauno Koivisto johti päättäväisesti tätä prosessia.

Euroopan Unionissa laajennushankkeet konkretisoituivat. Neuvottelut Euroopan talousalueesta keskeytyivät, ja Suomi, Ruotsi, Itävalta sekä Norja hakivat EY:n jäsenyyttä, joka toteutui vuonna 1995. Norja tosin jäi EU:n ulkopuolelle kansanäänestyksen tuloksena.

EU:n laajentamista jatkettiin Euroopan ja maailman mullistusten sävyttämänä. Vuonna 2004 kymmenen uutta jäsenmaata liittyi Euroopan Unioniin. Myöskin NATO laajeni itään. Baltian maat liittyivät sekä EU:hun että Natoon. Itämeren strateginen tilanne muuttui perusteellisesti lyhyen ajan sisällä.

Edellä kuvatut 1990-luvulla tapahtuneet Euroopan poliittiset muutokset merkitsivät 
Suomen toisen maailmansodan jälkeisen ulko- ja turvallisuuspoliittisen asetelman perusteellista uudistumista. Muutoksen syvyyteen nähden erittäin laajakantoiset päätökset tehtiin pragmaattisesti ja melko laajan konsensuksen turvin. Suomi todisti olevansa kykenevä reagoimaan muuttuviin olosuhteisiin vastuullisesti ja nopeasti.

SDP oli Harri Holkerin johtaman sinipunahallituksen toinen pääosapuoli Neuvostoliiton muutosprosessin kiihtyessä 1990-luvun taitteessa. Suomen ja Neuvostoliiton välisen clearingkaupan lakkauttaminen oli konkreettinen esimerkki muuttuneesta ajasta. Vuoden 1991 eduskuntavaalien seurauksena SDP siirtyi oppositioon. Se oli kuitenkin Esko Ahon hallituksen oppositiopuolueenakin Suomen EU-jäsenyyden johtava puolestapuhuja. Vuoden 1995 eduskuntavaaleissa SDP oli selvä vaalivoittaja, ja enemmistöhallitus muodostettiin Paavo Lipposen johdolla. SDP jatkoi myös presidenttipuolueena, kun Martti Ahtisaari jatkoi Mauno Koiviston työtä voitettuaan presidentinvaalit vuonna 1994.

SDP:ssä vallitsi koko nyt esillä olevan tapahtumaketjun ajan laaja yksimielisyys toimenpiteiden suunnasta ja sisällöstä. Mainittakoon, että SDP:n puoluekokoukset hyväksyivät Suomen EU-jäsenyyden yksimielisin päätöksin sekä vuonna 1991 että kahta vuotta myöhemmin.

Suurten, mullistavien tapahtumien jälkeen on tapana kysyä, missä olit kun mullistus tapahtui. Näin on kysytty myös Neuvostoliitossa elokuussa 1991 tapahtuneen vallankaappausyritykseen yhteydessä. Olin siihen aikaan vielä STS-pankin pääjohtaja, mutta seurasin kuitenkin läheltä SDP:ssä käynnissä olevaa keskustelua puolueen asemasta ja toiminnasta vaalitappion jälkimainingeissa. Esillä oli jo silloin ollut ajatus ylimääräisen puoluekokouksen tarpeellisuudesta. Se pidettiin marraskuussa 1991, ja minut valittiin SDP:n puheenjohtajaksi.

Mutta elokuun 19. päivänä olin Islannissa pohjoismaisessa kokouksessa. Heräsin ho- tellissani Reykjavikissa aikaisin, sillä olimme lähdössä pienellä porukalla Islannin osuustoimintaliikkeen pääjohtajan lohijoelle noin 100 kilometrin päähän pääkaupungista itään. Televisiossa Sky News näytti uutisen Moskovan tapahtumista. Oli kuvia panssarivaunuista ja neuvottelupöydän takana istuvista vakavan oloisista ja väsyneen näköisistä miehistä.

Minulle selvisi pian, että kyse oli poikkeustilan julistamisesta ja tunnistin myös pian osan komitean jäsenistä, ennen kaikkea komitean johtajan, varapresidentti Gennadi Janajevin, jonka olin tavannut henkilökohtaisesti lukuisia kertoja vuosien varrella. Ei ollut vaikeaa havaita, että Janajev vaikutti epävarmalta ja hermostuneelta, kun hän vapisevin käsin luki komitean tiedonannon. Epäselvä puhe viittasi myös siihen, että edellinen yö oli venynyt pitkäksi.

Nousin nopeasti ja soitin ensimmäisenä Helsinkiin pankin tiedotuspäällikölle, jolta pyysin telexillä kaikkea mitä Suomessa tiedotettiin Moskovan tapahtumista. Sen jälkeen soitin hyvälle ystävälleni, Suomen Islannin suurlähettiläälle Håkan Brandersille, joka Reykjavikin aamutunnelmissa oli yhtä tietämätön Moskovan tapahtumista kuin minäkin. Hän oli saanut Suomen ulkoministeriön tiedotteen, jossa vain todettiin, että tilannetta seurataan.

Lupasin lähettää hänelle kaiken materiaalin mitä saan Helsingistä. Sitä tulikin pian metrikaupalla.

Lähdimme sitten suunnitelman mukaan isäntämme kesänviettopaikalle Heklan eteläpuolelle lähelle meren rantaa, erittäin luonnonkauniille paikalle. Isännällämme oli oma viiden kilometrin jokiosuus, ja joessa oli hyvin kalaa. Kalastuksen lomassa pidimme uutistaukoja ja seurasimme Sky Newsin uutisia Moskovan tapahtumista. Siellä näimme Boris Jeltsinin nousevan tankin päälle Moskovan Valkoisen talon edessä, ja totesimme, että kaappaus oli ilmeisesti päättymässä. Tiedostimme kyllä, että tapahtumat eivät jäisi siihen, ja valoimme kannuja siitä, mitä tapahtuu seuraavaksi. Ja eivätpä tapahtumat totisesti siihen jääneet. 